\title{
Assessing the Balanced Scorecard as a Performance Measurement System in Travel Agencies
}

\author{
Hamida Abd El Samie Mohamed EI Sayed \\ Lecturer, Tourism Studies Department \\ Faculty of Tourism and Hotels, University of Sadat City
}

\begin{abstract}
The balanced scorecard (BSC) has gained its popularity as a performance measurement system in all sectors, such as manufacturing and services. The BSC is built upon four main areas, respectively; learning and growth, internal business process, customer and financial perspectives. The key objective of this research is to examine the applicability of the BSC as a tool for performance measurement at travel agencies in Egypt. The literature introduces the definitions of BSC, its benefits and limitations. The study is exploratory in nature, utilizing online structured questionnaire which is directed to tourism managers. A sample size of (86) managers has been introduced in this research. The main findings of the practical study revealed that even though the BSC measures have been used extensively in the travel agencies, the respondents' managers weren't aware of the BSC concept. That result clarifies that there isn't a relationship between using the measures of BSC and the awareness of that concept. The study also identified the key challenges that could face travel agencies when implementing $B S C$.
\end{abstract}

Keywords: performance measurement, balanced scorecard, performance measurement system, travel agencies, strategy mapping.

\section{Introduction}

Performance measurement is an important system for managing control for businesses (Zhang et al. 2013). It is directly related to the formation and maintenance of a firm's core competency and has an impact on the firm's growth and achievement of competitive advantage (Zhang et al. 2013, p.69). According to Chan (2003) performance measurement describes the feedback or information on activities with respect to meeting customer expectations and strategic objectives. Performance measurement can be done in a systematic way for the entire organization and it might be done temporarily or for a particular purpose (Öztürk \& Coskun, 2014). Organizations usually practice performance measurement to examine important issues, such as identifying the needs of customers and who's ability to meet these needs; considering if they are successful generally; making sure that the taken decisions are built on facts not on emotions or assumptions and finally revealing problem fields (Parker, 2000). Despite the huge performance measurement literature for the manufacturing sectors, little research has been conducted for the tourism industry (Yilmaz \& Bititci, 2006). 
Performance measurement system (PMS) is considered one of the most important topic and technique in the field of business management (Zeglat et al. 2012). Neely et al. (2005, p. 1229) refer to the performance measurement system (PMS) as the set of metrics (measures) used to quantify both efficiency and effectiveness. Performance measurement system can be defined as a technique to allocate responsibilities and decision rights, set performance targets, and reward the achievement of targets (Farooq \& Hussain, 2011; Lee \& Yang, 2011). In order to help researchers and users of performance measurement systems to identify its functions, Franco-Santos et al. (2007) summarized these functions into five main areas. The first area is that of measuring business performance. The second area involves in introducing and deploying strategic management philosophies into a company. The third area involves facilitating communications within the company as well as with parties outside of the company (i.e. internal and external communications). The fourth area involves influencing behavior through deciding and monitoring rewards and the fifth area is learning and continuous improvement function, which is accomplished by conducting feedback processes in order to improve future performance. Literature indicates that performance measurement is commonly based on financial measures (Panicker \& Seshadri, 2013). Nevertheless it is well known that financial measures are mostly effective in the short term, only (Panicker \& Seshadri, 2013; Basuony, 2014). Top management needs more than traditional financial measures to run their businesses in a better way (McCunn, 1998). Therefore, the BSC was originally proposed to overcome the limitations of managing with only financial measures (Basuony, 2014).

The balanced scorecard (BSC) seems to be the latest management fashion to sweep the organizational world (Malmi, 2001, p.207).The originating heroes of the balanced scorecard (BSC), Professor Robert Kaplan and David Norton, developed a useful tool for the companies to be able to translate their mission and strategy into a comprehensive set of performance measures and to provide the framework for strategic measurement and management (Borza \& Bordean, 2006).It is particularly notable that the BSC has gained wide acceptance within the service sector (Bharadwaj $\&$ Menon, 1993).A considerable number of studies have employed the BSC concept to examine the performance of hotels and tourism enterprises(Denton \& White, 2000; Feng et al., 2003; Evans, 2005; Phillips \& Louvieris, 2005). The balanced scorecard model (Kaplan \& Norton, 1992) is one of a number of performance measurement and management tools used in the hospitality industry in order to execute strategy (Quintano, 2009, p.5).

The purpose of this paper is to focus on BSC and its implementation in travel agencies. This research aims to review the BSC literature as a performance measurement system. Then, it will go further to determine the extent to which BSC approach has been applied in travel agencies. Finally the research will identify the challenges facing travel agencies in the implementation of the BSC.

The paper is divided into four main sections. Section one presents a brief review of the BSC literature. Section two describes the methodology, research frame, as well as the analytical tests. Section three discusses the main results of the survey. The final 
section closes with the remarkable conclusions. The field study is also guided by the following questions:

1- What are the most common measures travel agencies use to assess their performance?

2- Do travel agencies aware of the BSC framework?

3- What are the key challenges facing travel agencies in implementing the BSC?

\section{Literature Review}

Defining Balanced Scorecard: There is no common definition for a balanced scorecard (Waruhiu, 2014). Some organizations considered it a tool for strategic planning, others have used it as a performance management system while yet others have used it as a management information system aimed at equipping managers with data and information for enhancing decision making (Waruhiu, 2014). The balanced scorecard is a carefully selected set of quantifiable measures derived from an organization's strategy and used to align the organization's short-term actions with this strategy, while allowing strategy to evolve in response to changes in the company's competitive, market and technological environments, and used to assess the effectiveness of these actions in achieving the organization's strategic objectives (Frechtling, 2006,p.1). BSC is a multidimensional approach to measuring and managing performance that is specifically related to organizational strategy. The emphasis is on linking performance measures with the strategies of the business units (Otley, 1999). The BSC is a framework for performance measurement that focuses the attention of managers in just a few steps and makes linkages between different functional areas (Akkermans \& Oorschot, 2002).

BSC can be applied in companies of any size to manage and evaluate business strategy, monitor operation efficiency, and communicate related processes to all employees (Rohm, 2006). In addition to the balance achieved by examining both financial and nonfinancial performance indicators, the balanced scorecard helps managers improve corporate decision making and accountability by including both leading and lagging measures of performance (Epstein \& Wisner, 2001). Leading indicators are generally regarded as inputs or process indicators that link more closely to operations, while lagging indicators relate more to outcomes achieved through the management of leading indicators (Epstein \& Wisner, 2001).

The "balance" in the BSC relates to three areas (Niven, 2002); balance between financial and non-financial indicators of success, balance between internal and external stakeholders and then balance between lag and lead indicators of success.

According to Kaplan and Norton (1996 a), the BSC is composed of four strategic perspectives: financial, customer, internal business process and learning and growth ones; ten to fifteen strategic objectives distributed among the four perspectives; at least two indicators to measure each strategic objective; targets and initiatives to reach the targets.

Each perspective of the balanced scorecard includes objectives, measures of those objectives (metrics), target values of those measures, and initiatives needed to achieve targets (Pandey, 2005).Objectives: The Company specifies major objectives to be 
achieved under each perspective. For example, under the financial perspective, it may identify profitable growth as the major objective. Measures: Measures are the indicators that measure progress towards reaching the objective. For example, the financial objective of profitable growth might be measured by growth in revenues and profits. Targets: Targets are the values for the measures. For example, the company may propose that in the five-year planning period, revenue should grow at 10 per cent per annum. Initiatives: Initiatives are the actions needed to be performed to achieve objectives and targets. For example, a 10 per cent revenue growth may be achieved by spending specified money on massive advertising and introducing new products.

Balanced Scorecard Perspectives: The origins of the word "perspective" is from the Latin word perspectus, "to look through" or "see clearly," which is precisely what organizations aim to do with a balanced scorecard: examine the strategy and making it clearer through the lens of different viewpoints (Niven, 2006). The balanced scorecard developed by Kaplan and Norton (1992) suggests a sequence of four perspectives that reflects the value-creating activities of the company. The sequence begins with the learning and growth perspective, followed by the internal/business process; the customer perspective serves as the third perspective and the financial perspective serves as the final one (Kaplan \& Norton, 1992).A typical scorecard includes four components (as shown in Figure 1).

Learning and Growth perspective: This perspective represents the ability of employees, information systems, and organizational alignment to manage the business and adapt to change (Huang et al. 2007). Intense global competition forces companies to make continual improvements to their existing products and processes and gain the ability to introduce entirely new products with expanded capabilities (Kaplan \& Norton 2005).A company's ability to innovate, improve, and learn links directly to the company's value (Kaplan \& Norton, 2005). That can be done through the ability to launch new products, create more value for customers, improve operating efficiencies, penetrate new markets, increase revenues and margins - and finally increase shareholder value (Kaplan \& Norton, 2005).This is also the case of the tourism agencies which abilities to innovate, improve and learn can help them win the battle with their competitors (Borza \& Bordean, 2006). A tourism company can use multiple measures for the innovation and learning perspective: new products launched, new markets identified, staff appraisal, staff targets, courses completed, improvements identified (Borza \& Bordean, 2006).

Internal business perspective: The internal measures for the balanced scorecard should originate from the business processes that have the greatest impact on customer satisfaction - factors that affect cycle time, quality, employee skills, and productivity (Kaplan \& Norton, 2005). Companies should decide what processes, critical technologies and core competencies they must excel at and specify measures for each (Kaplan \& Norton, 2005). This perspective is also described as an internal value chain, which begins with identifying what the customers need, investigating the market for those needs, creating a product or service to satisfy the need, delivering the product or service and following-up with any post-delivery issues (Kaplan \& Norton, 1996b). For a tourism agency those could be translated into the capacity of offering 
the best alternative for the costumers or the employee's attitude towards the costumers (Borza \& Bordean, 2006, p.107).Managers can use multiple indicators to measure the internal performance of their organizations such as: employee turnover, revenue by segment, complaint responses. By measuring these indicators, the manager can realize a general image about the internal situation of his company, about the things that are working and those that are not working (Borza \& Bordean, 2006).

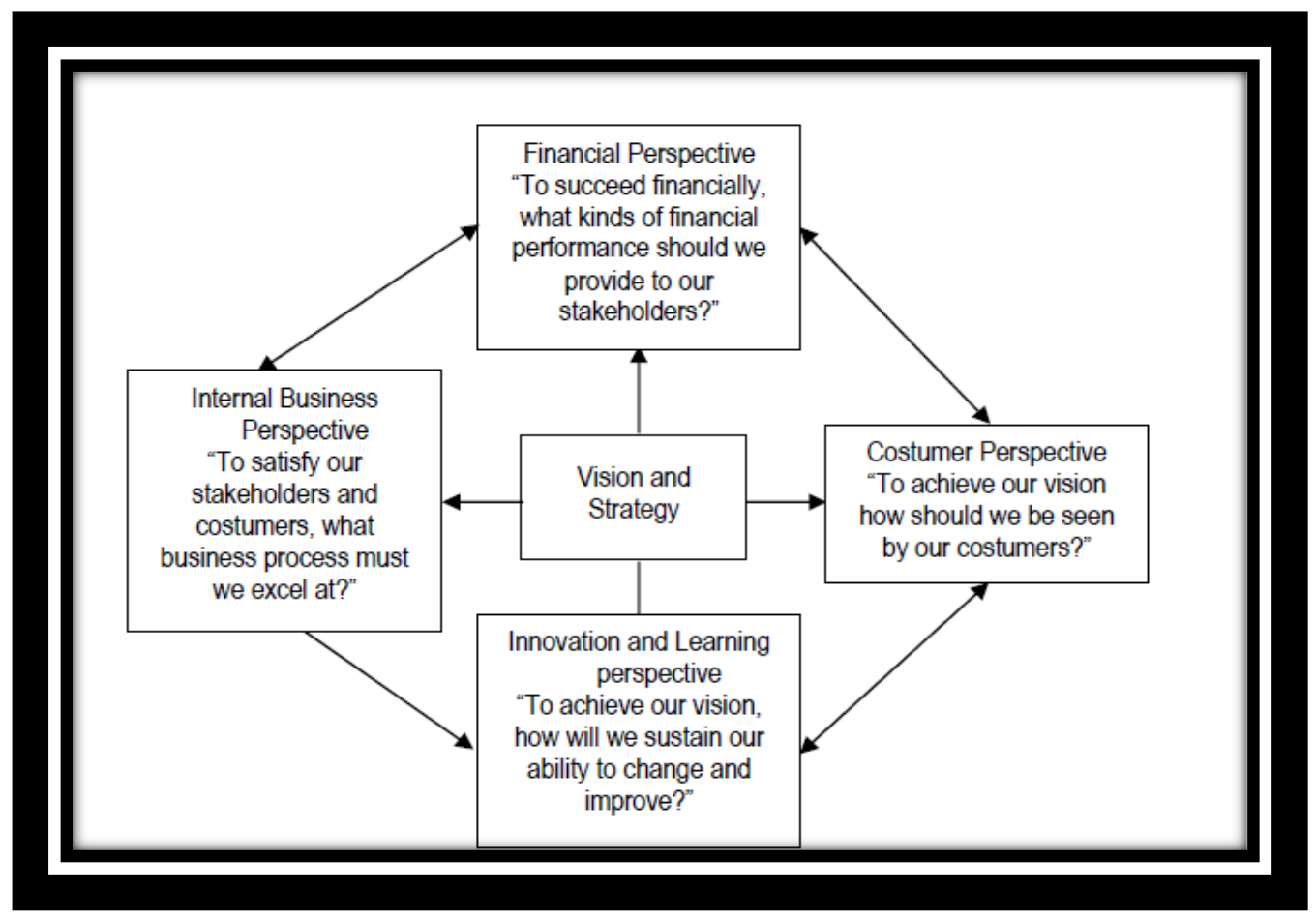

Figure 1: The Balanced Scorecard, Source: Kaplan and Norton 1996a:76.

Costumer perspective: This is the strategy for creating value and differentiation from the perspective of the customer .Distinctive measures used under this perspective are: customer satisfaction, customer complaints, customer lost/won, sales from new products (Panicker \& Seshadri, 2013, p.36). Some studies have found a significant association between customer satisfaction and performance (Ittner \& Larcker, 1998; Banker et al. 2000). Kaplan and Norton (1996b) have determined three broad-based themes of customer's values. The first category is product or service attributes, such as uniqueness, functionality, quality, price and time. The second category is customer relationships, which includes attributes such as convenience, trust, and responsiveness. The third category or theme is image and reputation and includes attributes such as innovation and stature in the market (Kaplan \& Norton, 1996b). The tourism agencies like any other businesses that act in the in the service sector, have to consider the costumer's needs in order to better satisfy them (Borza \& Bordean, 2006). Serving the costumer in a short time, by offering him the best solution (that could materialize into 
a plane ticket, a reservation for a hotel or a booked holiday) will have a positive effect upon him that could reflect later in the financial perspective of the company (Borza \& Bordean, 2006,p.107). The difference between a tourism agency that adopts the balanced scorecard and that doesn't adopt it is that the first one will articulate goals and afterwards, it will try to translate these goals into specific measures (Borza \& Bordean, 2006). For a tourism agency it will be appropriately to measure indicators like: customer satisfaction, local market share, number of complaints, returning costumers (Borza \& Bordean, 2006, p.107).

Financial perspective: Under this perspective the common performance measures included are: ROI, Cash Flow, Net Operating Income and Revenue Growth (Panicker \& Seshadri, 2013). Typical goals that can be identified in this part of the balanced scorecard refer to profitability, growth and shareholder value. A certain number of indicators can be considered when referring to the financial perspective: total operating revenue, comparison between costs and budget, comparison of the financial performance with the competitors (Borza \& Bordean, 2006). The financial perspective includes three measures that are strongly related to shareholders. Return on capital employed and cash flow reflect preferences for short-term results, and forecast reliability indicates the corporate parent's desire to reduce the historical uncertainty caused by unexpected variations in performance (Huang et al. 2007).

Kaplan and Norton (2003) also created a powerful tool, the 'strategy map', that enables companies to describe the links between intangible assets and value creation with a level of clarity and precision that has never before been possible. The strategy map is a general, logical and comprehensive mechanism for describing the network of cause-and-effect relationships between the organization strategy and the activities that employees do daily (Kaplan \& Norton, 2000).Strategy mapping provides an opportunity to translate the key strategies or initiatives that management intends to adopt to achieve the strategic objectives (Murby\& Gould, 2005). The strategy map (as shown in figure 2) is a one-page graphical representation of what the organization must do well in each of the four perspectives if it hopes to execute its strategy (Niven, 2006 ,p.27). 


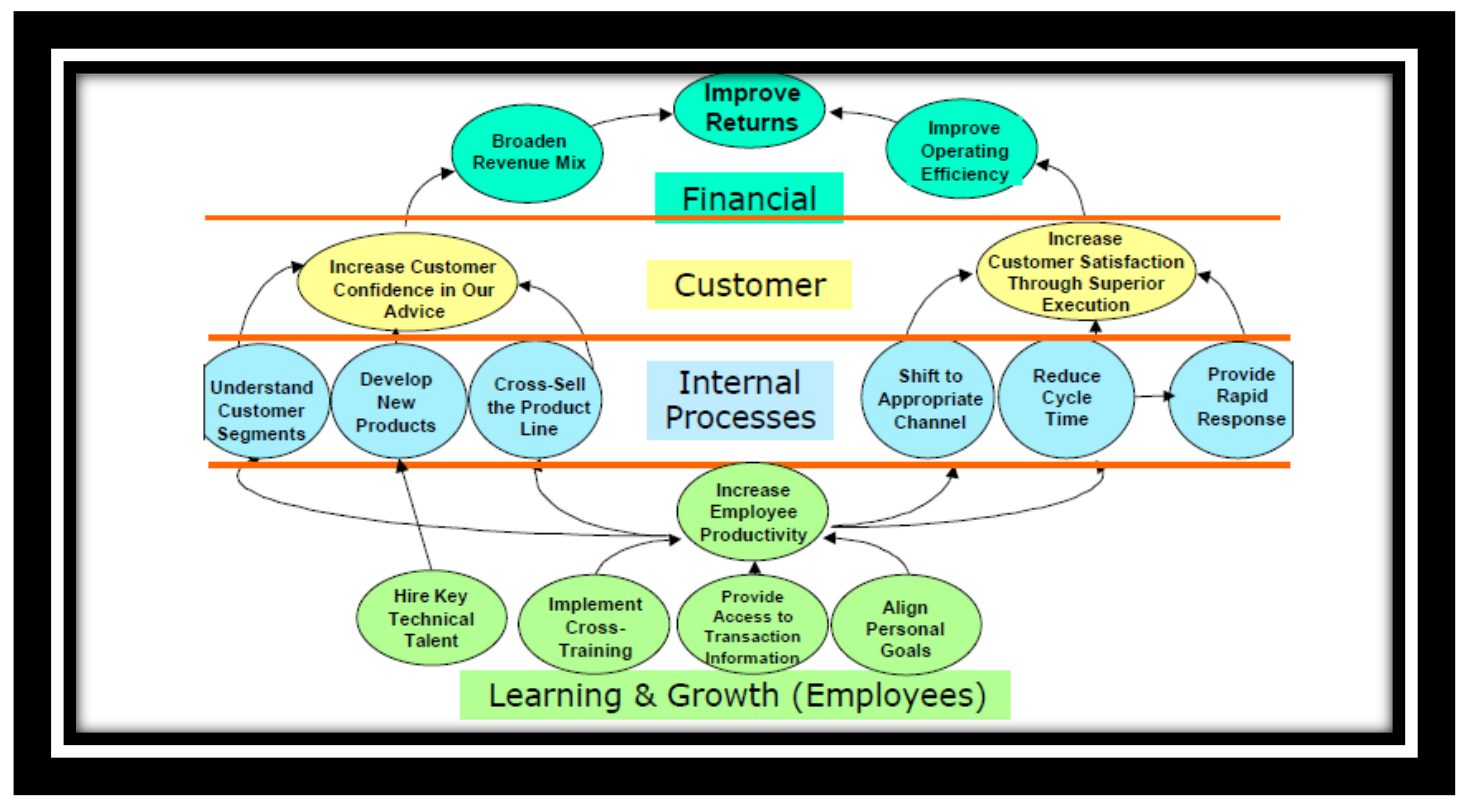

Figure 2.Strategic Mapping, Source: Rohm 2002:4

BSC and the Other Performance Management Systems: Through using the performance measurement tools, companies can monitor the implementation of their business plans and strategies, therefore contributing to their organizational success (Gomes \& Romao, 2012). Salem et al.(2012) compare BSC with other performance management systems:

1. Total Quality Management (TQM) -TQM focuses on the system of the organization as a whole. On the other hand, BSC heavily emphasizes on financial aspects. Both systems are used to integrate the performance management and control systems, focusing on communication, reducing the cost, and emphasizing the importance of organizations.

2. ISO14001 - The main difference between BSC and ISO14001 is that BSC is a strategy management tool, which focuses on whole of the organization, Whereas, ISO14001 is a system that focuses on environmental issues.

3. European Foundation Quality Management (EFQM) - The EFQM is a practical tool to help organization determining their exact position on the path of excellence. The BSC and the EFQM are tools that use measures of organizational performance for the purpose of the improvement, and both have been widely adopted. The BSC design processes starts with the articulation of a shared strategic vision and backwards to define the priority strategic activities and outcomes. In contrary, the EFQM assesses performance against the activities standard.

4. Management by Objectives (MBO) - In MBO, each goal is determined through agreement between managers and subordinates. A total goal is composed of section's goals, and each section's goal is composed of individual's goals. It 
focuses on employees' participation and considers the employees' motivation. MBO requires eight areas in business, what makes MBO more complex than BSC.

Benefits of Adopting Balanced Scorecard: By combining the four perspectives, the balanced scorecard helps managers understand the interrelationships and causal effects among the various aspects (Huang et al. 2007). This understanding enables managers to remove the functional barriers and ultimately improves their capabilities in decision making and problem solving (Frigo,2004; Poureisa et al. 2013). BSC can play an important role in change management (Kaplan and Norton 1996a).An effective BSC will shape the strategic direction of the company, the motivation for that strategic direction, and how it will improve the organization's performance(Whitaker, 2001).

Reviewed literature presents three studies to associate BSC usage and improved organizational performance (Davis \& Albright, 2004). Hoque and James (2000) surveyed Australian manufacturing firms on their usage of nonfinancial measures typically found in discussions of BSC development. Their results indicate a significantly positive relationship between the usage of typical BSC measures and superior performance (Hoque \& James, 2000). Malina and Selto (2001) also investigate the effectiveness of the BSC in communicating strategic objectives and serving as a management control device. They find evidence of an indirect relationship between BSC's management control function and improved performance on BSC measures (Malina \& Selto, 2001). Banker et al. (2000) examined the association between improved financial performance and non-financial metrics in a hotel chain where a new incentive program included an emphasis on customer satisfaction performance measures. They found evidence of a relationship between customer satisfaction, non-financial metrics and future financial performance (Banker et al. 2000).

The scorecard wasn't a replacement for financial measures; it was their complement(Kaplan \& Norton, 1996a). The scorecard enables managers introduce four new management processes (Kaplan \& Norton 1996a) The first new process translating the vision - helps managers build a consensus around the organization's vision and strategy. The second process - communicating and linking managers communicate their strategy up and down the organization and link it to departmental and individual objectives. The third process - business planning - enables companies to integrate their business and financial plans. The fourth process - feedback and learning - offers companies the opportunity for strategic learning. The scorecard thus enables companies to modify strategies to reflect real-time learning. 


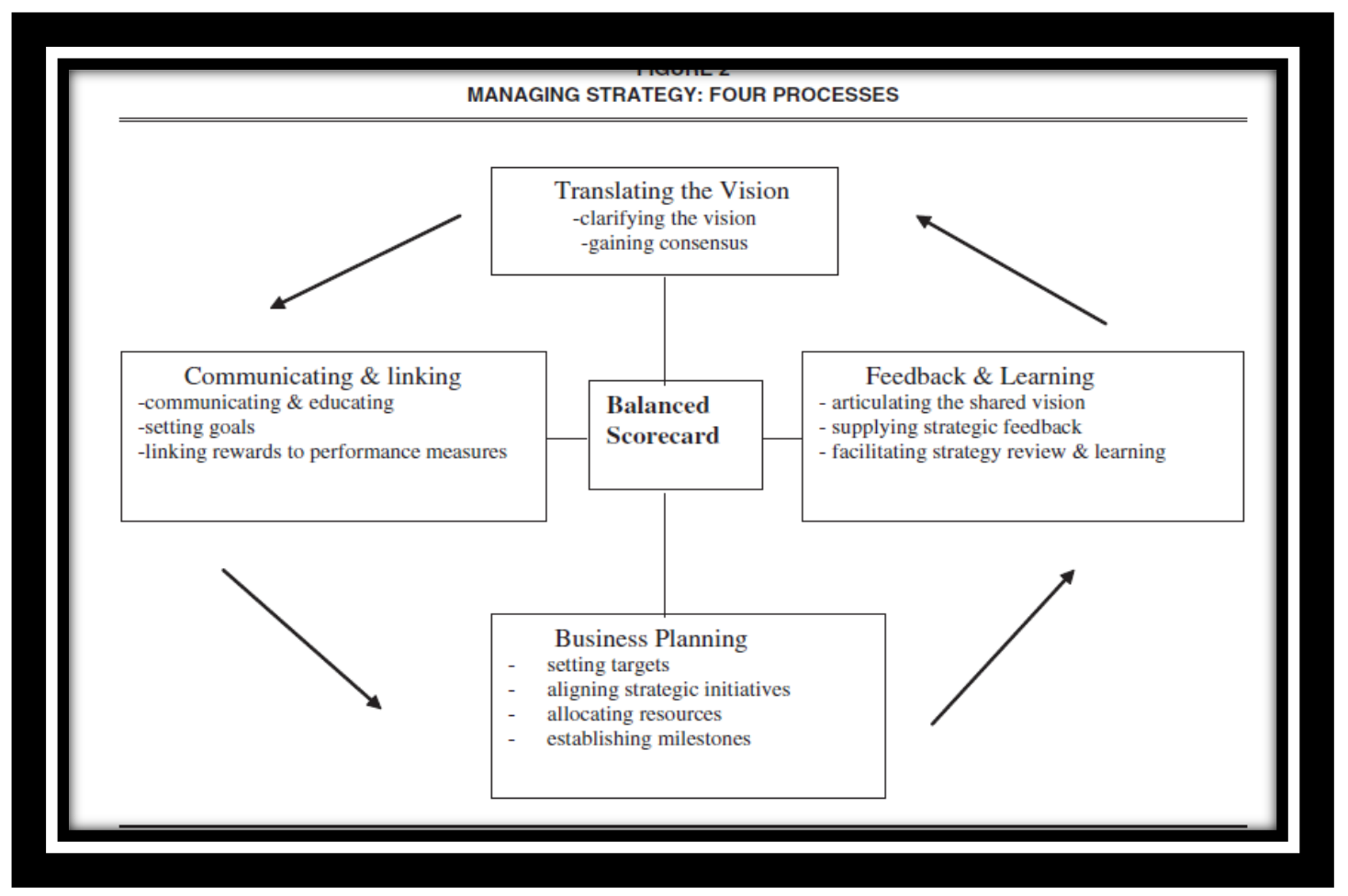

Figure 3.Managing Strategy: Four Processes, Source: Kaplan and Norton (1996a)

In summary, the BSC helps an organization in the following six ways (Gumbus \& Lussier, 2006): Promotes growth - due to focus on long-term strategic outcomes, not just short-term operational results. Tracks performance-individual and collective results can be tracked against targets in order to correct and improve. Provides focus - when measures are aligned to a few critical strategies, the BSC provides focus on what is important to the company. Alignment to goals - when you measure what is truly important to success; the measures become linked and support each other. Alignment occurs across the organization. Goal clarity - the BSC helps responding to the question, "How does what I do daily contribute to the goals of the enterprise?"

Accountability - individuals are assigned as owners of metrics in order to provide clear accountability for results.

Challenges in the Implementation of the Balanced Scorecard: Despite the above mentioned benefits, it has been concluded that the process of adopting the BSC is complex and requires the commitment of resources and time to monitoring, continuous learning, feedback and adjustments (Doran et al. 2002).Problems have been regarded such as: its key assumptions and relationships (Norrekilt,2000); not providing guidance as to how to improve performance to achieve the desired strategic results 
(Gautraeu \& Kleiner, 2001); its confusion of cause and effect with finality (Norrekilt, 2000); being costly in terms of cash and time (Lipe \& Salterio, 2000; Gautraeu \& Kleiner, 2001); the volume of data may overload human decision-makers (Lipe \& Salterio, 2002).

Moreover, it has been suggested that many of the BSC projects either fail or do not occur (Nyaega, 2006). Graham (2003) criticized the BSC as being too expensive. Measures developed for an organization should always be balanced and easy to interpret (Branice, 2013). Using too many measures leads to loss of balance (Branice 2013). Measures should be few in number, but highly relevant and focused on improvement rather than the achievement of a measure (Mbogo, 2008). Butler et al. (1997) considers Kaplan and Norton's model to be too general. Laitinen (1996) also considers the selection of (four) basic dimensions and their interrelationships problematic. Letza (1996) concludes the greatest threat can occur if managers select the wrong measures, group these into the four proposed perspectives and then focus on the wrong issues.

Kaplan and Norton (2001) identify two sources of the failure of the balanced scorecard in large companies: the design and the process.

Design failure: A poorly designed balanced scorecard may lead to its failure in an organization. A poor design includes: Too few measures in each perspective, leading to failure to obtain a balance between leading and lagging indicators or financial and non-financial indicators. Too many indicators without identifying the critical few: in this case, the organization will lose control and be unable to find linkage between indicators. Failure of measures selected to describe the organization's strategy. This happens when an organization tries to enter all its Key Performance Indicators (KPIs) into each perspective without screening to select only those measures linked to its strategy. This means the organization's strategy is not translated into action and it thus does not obtain any benefit from the balanced scorecard.

Process failure: Process failures are the most common causes of failure of the Balanced Scorecard and include (Kaplan \& Norton, 2001): Lack of senior management commitment, too few individuals involved, overly long development process, treating the balanced scorecard as a one-time measurement project, hiring inexperience consultants

Balanced Scorecard Limitations: Not all stakeholders were included in the BSC such as: suppliers and public authorities (Atkinson et al. 1997; Norreklit, 2000). The BSC contains a serious failure in their construction, once it focused management strictly on a set of pre-defined indicators and measures without paying attention to the actions and strategies of the competitors (Kennerley \& Neely 2003; Norreklit, 2003). Any problem that can appear in the implementation of the strategy leads to achieve unbalanced situation between financial and non-financial measures (Anand et al. 2005). BSC has had different meanings at different times (Othman et al. 2006). In some cases, organizations do not understand what exactly the BSC is and what its implementation involves (Othman, 2009). 


\section{Material and Methods}

This study investigates the current adoption of the Balanced Scorecard in Egyptian travel agencies. In addition, this research aims to identify the various limitations associated with the implementation of the Balanced Scorecard in Egyptian travel agencies.

InSTRUMENT AND MEASURES: The study primary data was collected through structured questionnaires. The questionnaires were both closed and open-ended so as to let the respondents to express their views without restrictions. Questionnaires were sent for the tourism mangers via emails. The questionnaire was in the form of Likert scale where respondents were required to indicate their views on a scale of 1 to 5 . The questionnaire contained 3 sections: section A was on general information about the respondents, section $\mathrm{B}$ comprised of questions involving the extent of adoption the BSC framework in the Egyptian travel agencies grouped under financial, customer, internal business and learning and growth perspectives, while section $\mathrm{C}$ covered the possible challenges faced in implementing the BSC framework. Statistical Package for Social Sciences Software (SPSS) 16.0 was used to conduct statistical analysis of the data.

Participants: A total of 100 travel agencies managers, were used for the purpose of the study. Out of the target population (86) responded thus achieving a response rate of $86 \%, 65$ males and 21 females. The mean age of participants was 46 years old. Of the participants, 91\% had baccalaureate degree, and 9\% had earned an advanced degree. $81 \%$ of the participated mangers were not aware of BSC concept and 19\% only were aware of it.

RELIABILITY AND VALIDITY: To verify how closely the survey measurements met the objectives of this study, a reliability analysis was performed for the constructs composed by Cronbach's alpha. The generally agreed upon lower limit for Cronbach's alpha is 0.70 (Nunnaly, 1978). The results of the reliability of the balanced scorecard framework constructs gave alpha coefficients exceeding (.70), which are regarded as acceptable reliability coefficients. Hence, the results demonstrate that the questionnaire is a reliable measurement instrument.

Table 1.Cronbach's Alpha for balanced scorecard framework

\begin{tabular}{|c|c|}
\hline Construct & Cronbach's Alpha \\
\hline Financial Measures & .765 \\
\hline Customer Measures & .702 \\
\hline Internal Business Process Measures & .832 \\
\hline Learning and Growth Measures & .743 \\
\hline Challenges of implementing BSC & .920 \\
\hline
\end{tabular}




\section{Results and Discussion}

With regards to financial perspective, the respondents gave their answers on a scale of 1-5 where I represent to a very large extent and 5 very small extent. As table 2 shows, the total mean of using the different financial measures in determining the travel agencies performance was (3.56), with a standard deviation of $( \pm 1.01)$. The mean of applying the different financial measures was ranged from low (1.89) to Shareholder value analysis and a high of (4.87) to Profit margins. It is thus clear that measuring Profit margins and Percentage of sales growth are measures that are extensively used in the travel agencies followed by Return on travel agency assets, Cash flow management, Net operating income, Cost per operation hour and lastly Shareholder value analysis.

Table 2: Financial Measures

\begin{tabular}{|l|c|c|c|}
\hline & Measures & Mean & SD \\
\hline $\mathbf{1}$ & Percentage of sales growth. & 4.42 & .986 \\
\hline $\mathbf{2}$ & Return on travel agency assets. & 4.15 & .678 \\
\hline $\mathbf{3}$ & Profit margins. & 4.87 & .466 \\
\hline $\mathbf{4}$ & Cash flow management. & 3.76 & 1.45 \\
\hline $\mathbf{5}$ & Net operating income & 2.98 & .987 \\
\hline $\mathbf{6}$ & Cost per operation hour & 2.90 & 1.67 \\
\hline $\mathbf{7}$ & Shareholder value analysis & 1.89 & .876 \\
\hline \multicolumn{2}{|c|}{ Total } & $\mathbf{3 . 5 6}$ & $\mathbf{1 . 0 1}$ \\
\hline
\end{tabular}

Results in table 3 indicated that the travel agencies were keen to measure its performance by using customer measures. It is obvious that the total mean of the extent to which travel agencies use the customer measures in determining its performance, scored the highest mean (4.51) between all the used tools in determining the travel agencies performance with a standard deviation of $( \pm .761)$.

Table 3: Customer Measures

\begin{tabular}{|c|c|c|c|}
\hline & Measures & Mean & SD \\
\hline $\mathbf{1}$ & Customer satisfaction. & 4.61 & .456 \\
\hline $\mathbf{2}$ & Number of customer complaints. & 4.71 & .872 \\
\hline $\mathbf{3}$ & $\begin{array}{c}\text { Product or service attributes; } \\
\text { quality, price, time. }\end{array}$ & 4.43 & .625 \\
\hline & Customer retention rate. & 4.21 & .987 \\
\hline $\mathbf{4}$ & $\mathbf{5}$ & $\begin{array}{c}\text { The number of repeat versus new } \\
\text { customer orders. }\end{array}$ & 4.12 \\
\hline $\mathbf{6}$ & Customer increasing rate. & 4.42 & .928 \\
\hline
\end{tabular}




\begin{tabular}{|l|c|c|c|}
\hline $\mathbf{7}$ & Image and reputation. & 4.21 & .982 \\
\hline $\mathbf{8}$ & Customer loyalty. & 4.05 & .678 \\
\hline & Total & $\mathbf{4 . 5 1}$ & $\mathbf{. 7 6 1}$ \\
\hline
\end{tabular}

The mean of applying the different customer measures was ranged from (4.05) to customer loyalty and (4.71) to Number of customer complaints. It is thus clear that measuring Number of customer complaints and Customer satisfaction are measures that are extensively used in the travel agencies in determining its performance. This result is in line with Borza and Bordean (2006) study that confirms that tourism agencies have to consider the costumer's needs in order to better satisfy them. This also supports the findings of Nusair and Kandampully (2008) who confirmed that customer focused enterprises will in fact enhance the firms' opportunity to improve sales.

Table 4 highlighted the adoption of internal business measures; the total mean was very low (2.62) with a standard deviation of ( \pm .825$)$. The mean of using internal business process measures in determining the travel agencies performance was ranged from low (1.56) to Employee turnover and a high of (4.23) Number of customer complaints responses. It is thus clear that Number of customer complaints responses and Post-sales services are measures that are extensively used in the travel agencies, while Employee turnover is considered the least frequently used with mean of (1.56) and standard deviation ( \pm .962$)$. This result asserted the findings of Qiu and $\mathrm{Wu}$ (2004) study that more efforts should be given to employee turnover as it is considered one of the major challenges in tourism sector.

Table 4: Internal Business Process Measures

\begin{tabular}{|c|c|c|c|}
\hline & Measures & Mean & SD \\
\hline $\mathbf{1}$ & $\begin{array}{c}\text { Number of customer complaints } \\
\text { responses. }\end{array}$ & 4.23 & 1.341 \\
\hline $\mathbf{2}$ & Number of new services offered. & 3.41 & .786 \\
\hline $\mathbf{3}$ & Total inventory cost. & 1.76 & .799 \\
\hline $\mathbf{4}$ & Transaction efficiency. & 1.89 & .234 \\
\hline $\mathbf{5}$ & Management performance. & 1.87 & .890 \\
\hline $\mathbf{6}$ & Post-sales services. & 3.67 & .765 \\
\hline $\mathbf{7}$ & Employee turnover. & 1.56 & .962 \\
\hline & Total & 2.62 & .825 \\
\hline
\end{tabular}

With respect to the learning and growth perspective, the results in table 5 indicated that information system capabilities and employee capabilities are the most widely used measures to indicate the travel agencies performance respectively. In terms of professional training the mean was (1.98) with standard deviation of (.345). That result 
indicates that travel agencies don't give the required attention for improving and training their employees. Travel agencies need to do more efforts in this concern as the study of Neely and Al Najjar (2006) shed the light on clarifying the true role of performance measurement for providing a means of management learning, rather than simply a means of management control. It is widely believed performance measures are essential if managers are to track progress and establish whether their organization is moving in the desired direction.

Table 5: Learning and Growth Measures

\begin{tabular}{|c|c|c|c|}
\hline & Measures & Mean & SD \\
\hline $\mathbf{1}$ & Employee stability. & 2.18 & .987 \\
\hline $\mathbf{2}$ & Professional training. & 1.98 & .345 \\
\hline $\mathbf{3}$ & Employee capabilities. & 4.34 & .567 \\
\hline $\mathbf{4}$ & $\begin{array}{c}\text { Information system } \\
\text { capabilities. }\end{array}$ & 4.87 & .539 \\
\hline $\mathbf{5}$ & $\begin{array}{c}\text { Empowerment and } \\
\text { alignment of employees. }\end{array}$ & 3.76 & .346 \\
\hline $\mathbf{6}$ & Employee satisfaction. & 3.21 & .981 \\
\hline $\mathbf{7}$ & Product innovation rate. & 2.76 & .346 \\
\hline & Total & 3.30 & .587 \\
\hline
\end{tabular}

The travel agencies managers were also requested to indicate the challenges faced when implementing the BSC .Results tabulated in table 6 confirmed that the challenges of applying BCS in travel agencies are arranged as follow,(1) Too difficult in determining measures (mean 4.98 and SD \pm .230), this confirms Graham (2003) who criticized the BSC as too expanded and too broad to be of specific use to most firms. (2)Too many measures to be used (mean 4.34and SD \pm .981 ), as we noticed from the study, it was established that the BSC measures are too many since each perspective has to have its own measures making the process very difficult to manage and apply . (3)Lack of skills and know how to developing BSC (mean 4.21 and SD \pm .781 ), (4) Lack of highly developed information systems (mean 3.45 and SD \pm .349 ), (5)Time consuming in developing and updating BSC(mean 3.24 and SD \pm .348 ), this can be attributed to the truth that when organizational structures are re-aligned and strategies are constantly changing the BSC measures also need development and updating. .Gatreau and Kleiner (2001) confirmed that continuously updating the scorecard needs 
a lot of time. (6)Selecting wrong measures (mean 3.23and SD \pm .921 )and lastly, (7)Lack of senior management commitment(mean 2.45and SD \pm .873 ).

Table 6: Challenges of BSC implementation

\begin{tabular}{|c|c|c|c|}
\hline & Challenges & Mean & SD \\
\hline $\mathbf{1}$ & $\begin{array}{c}\text { Time consuming in developing } \\
\text { and updating BSC }\end{array}$ & 3.24 & .348 \\
\hline $\mathbf{2}$ & Too many measures to be used & 4.34 & .981 \\
\hline $\mathbf{3}$ & $\begin{array}{c}\text { Too difficult in determining } \\
\text { measures }\end{array}$ & 4.98 & .230 \\
\hline $\mathbf{4}$ & $\begin{array}{c}\text { Lack of highly developed } \\
\text { information systems }\end{array}$ & 3.45 & .349 \\
\hline $\mathbf{5}$ & $\begin{array}{c}\text { Lack of skills and know how to } \\
\text { developing BSC }\end{array}$ & 4.21 & .781 \\
\hline $\mathbf{6}$ & Selecting wrong measures & 3.23 & .873 \\
\hline $\mathbf{7}$ & Lack of senior management \\
commitment & 2.45 & \\
\hline
\end{tabular}

To indicate the relationship between the level of awareness and the extent to which the travel agencies use BSC measures, a correlation analysis was conducted in table 7.

Table 7: Correlation analysis between the extent of applying BSC measures and the level of Awareness

\begin{tabular}{|c|c|c|c|}
\hline & & Awareness & $\begin{array}{l}\text { ApplyingBSC } \\
\text { measures }\end{array}$ \\
\hline \multirow[t]{3}{*}{$\begin{array}{c}\text { AwarenessLevel } \\
\text { of }\end{array}$} & $\begin{array}{c}\text { Pearson } \\
\text { Correlation }\end{array}$ & 1 & 0.11 \\
\hline & Sig.(2-Tailed) & ---- & 0.76 \\
\hline & $\mathrm{N}$ & 86 & 86 \\
\hline \multirow[t]{3}{*}{$\begin{array}{c}\text { Applying BSC } \\
\text { Measures }\end{array}$} & $\begin{array}{c}\text { Pearson } \\
\text { Correlation }\end{array}$ & 0.11 & 1 \\
\hline & Sig. (2-Tailed) & 0.76 & --- \\
\hline & $\mathrm{N}$ & 86 & 86 \\
\hline
\end{tabular}


The correlation analysis showed that the value of correlation coefficient " $r$ " is low for the relationship between awareness and the extent to which the travel agencies use BSC measures among respondents $(r=0.11, \operatorname{sig}=0.76)$. This value indicates there is no relationship between the level of awareness and the extent of applying the BSC measures in the travel agencies.

\section{Conclusion}

BSC isa performance measurement system based not only on the financial measures but also on non-financial measures like customer factors, internal business processes, and employee learning and growth. A considerable number of studies have employed the BSC concept to examine the performance of hotels and tourism enterprises. The BSC helps an organization in the following six ways: promotes growth, tracks performance, provide focus, alignment to goals, goals clarity and accountability. The key objectives of this study were to identify the extent to which the BSC framework is applied in the Egyptian travel agencies and to settle on the challenges of its implementation .In order to fulfill the study objectives, the practical study were undertaken to identify the most common measures travel agencies use to assess their performance. Although tourism managers practiced some measures of the BSC framework, they were not aware of the BSC concept itself. This result is in line with Othman (2009) study that confirms that in some cases, organizations do not understand what exactly the BSC is and what its implementation involves According to their mean values, the common measures were arranged respectively as follows; customer measures (4.51), financial measures (3.56), learning and growth measures (3.30) and finally internal business measures (2.62).Various challenges have been faced in the implementation of BSC in travel agencies, these challenges can be arranged as follow:(1) too difficult in determining measures, (2) too many measures to be used,(3) lack of skills and know how in developing BSC (4) lack of highly developed information systems,(5)time consuming in developing and updating BSC(6)selecting wrong measures, and (7lack of senior management commitment. The challenges that the travel agencies face are the tool which can be used for the continuous development for BSC.

\section{Recommendations}

If the challenges are used as benchmarks, implementing the $\mathrm{BSC}$ and overcoming the challenges will enable travel agencies to wholly adopt the BSC. Measuring performance is the only way for successful business. Travel agencies should rethink their strategies of assessing their performance, adopting performance measurement systems like BSC is a must. Special attention should be given to the perspective of internal business process as it diagnoses the internal situation in any organization. In order to effectively build BSC, special considerations should be adopted. Managers need to arrange project team that is well trained on how to use BSC. Top management support is essential requirement. Furthermore, managers need to select simple measures under each component. The BSC should be aligned with the organization's 
strategy. Automated data and improved IT software systems can facilitate the process of building BSC framework.

\section{References}

- Akkermans, H. and Von Oorschot, K. (2002). 'Developing a Balanced Scorecard with System Dynamics',Journal of the Operational Research Society May, pp.1-22.

- Anand, M., Sahay, B., and Saha, S. (2005). 'Balanced Scorecard in Indian Companies', Vikalpa, 30, pp.1125.

- Atkinson, A., Waterhouse, J., and Wells, R. (1997). 'A Stakeholder Approach to Strategic Performance Measurement'. Sloan Management Review, 38(3), p.5.

- Banker, R.D., Potter, G. and Srinivasan, D. (2000). 'An Empirical Investigation of an Incentive Plan that Includes Nonfinancial Performance Measures', Accounting Review, 75 (1), pp.65-92.

- Basuony, M. (2014). 'The Balanced Scorecard in Large Firms and SMEs: A Critique of the Nature, Value and Application', Accounting and Finance Research,3 (2), pp.14-22.

- Bharadwaj, S., and Menon, A. (1993). 'Determinants of Success in Service Industries', Journal of Services Marketing, 7(4), pp.19-39.

- Borza, A. and Bordean, O. (2006).'Performance Measuring of Small and Medium-sized Enterprises'. Management and Marketing. Paper presented at the International Conference on Business Excellence 27-28 October. Brasov, Romania.

- Branice, A. (2013).The Balanced Scorecard and Supply Chain Performance: A Case of Kenya Nut Company.MBA Thesis. The School of Business. University of Nairobi.

- Butler, A., Letza, S. R. and Neale, B. (1997). 'Linking the Balanced Scorecard to Strategy',International Journal of Strategic Management, 30(2), pp.242-53.

- Chan, F.T.S. (2003). 'Performance Measurement in a Supply Chain. 'International Journal of Advanced Manufacturing Technology, 21(7), pp.534-48.

- Davis, S. and Albright, T. (2004). 'An Investigation of the Effect of Balanced Scorecard Implementation on Financial Performance. 'Management Accounting Research, 15, pp.135-153.

- Denton, G.A. and White, B. (2000). 'Implementing a Balanced Scorecard Approach to Managing Hotel Operations: The Case of White Lodging Services. 'Cornell Hotel and Restaurant Administration Quarterly, February pp.16-26.

- Doran, M., Haddad, K., and Chow, C. (2002). 'Maximizing the Success of Balanced Scorecard Implementation in the Hospitality Industry.' International Journal of Hospitality and Tourism Administration, 3(3), pp.33-58.

- Epstein, M. and Wisner, P. (2001). 'Using a Balanced Scorecard to Implement Sustainability', Environmental Quality Management, pp.1-10.

- Evans, N. (2005). 'Assessing the Balanced Scorecard as a Management Tool for Hotel.' International Journal of Contemporary Hospitality Management, 17(5), pp.376-390.

- Farooq, A. and Hussain, Z. (2011).'Balance Scorecard Perspective of Change and Performance: A Study of Selected Indian Companies ', Journal of Global Strategic Management, 10, pp.37-48.

- Feng, R., Morrison, A.M. and Ismail, J.A. (2003). 'East versus West: A Comparison of Online Destination Marketing in China and the USA', Journal of Vacation Marketing, 10(1), pp.43-56.

- Franco-Santos, M., Kennerley, M., Micheli, P., Martinez, V., Mason, S., Marr, B., Gray, D. and Neely, A. (2007). Towards a Definition of a Business Performance Measurement System. International Journal of Operations \& Production Management. 27(8), pp.781-801.

- Frigo, M.L. (2004). 'Strategy and Execution: A Continual Process. 'Strategic Finance, 85(10), pp.7-9.

- Frechtling, D.C. (2006).A Balanced Scorecard System for Managing Strategy and Measuring Performance of Destination Management Organizations.[online] Available from: home.gwu.edu/frechti/material/BSCWorkingPaper4-06.pdf.(Accessed on: 28 March 2015).

- Gautreau, A. and Kleiner, H.B (2001).'Recent Trends in Performance Measurement Systems: The Balanced Scorecard Approach', Management Research News, 24(3), pp.153-56.

- Gomes, J., and Romao, M. (2012). Advantages and Limitations of Performance Measurement Tools: The Balanced $\quad$ Scorecard.[online]. $\quad$ Available from:www.reserachgate.net/profile/Jorge_Gomes/publications/260479716.pdf. (Accessed on: 17 March 2015).

- Graham, K. (2003). 'Balanced Scorecard' ,New Zealand Management, 50(2), pp.32-34.

- Gumbus, A. and Lussier, R. (2006). 'Entrepreneurs Use a Balanced Scorecard to Translate Strategy into Performance Measures' ,Journal of Small Business Management, 44(3), pp.407-25. 
- Hoque, Z., and James, W. (2000). 'Linking Balanced Scorecard Measures to Size and Market Factors: Impact on Organizational Performance ',Journal of Management Accounting Research, 12, pp.1-17.

- Huang, H. C, Chu, W. and Wang, W. (2007).'Strategic Performance Measurement and Value Drivers: Evidence from International Tourist Hotels in an Emerging Economy ', The Service Industries Journal, 27(8), pp.1111-1128.

- Ittner, C. D. and Larcker, D.F. (1998). 'Innovations in Performance Measurement: Trends and Research Implications' ,Journal of Management Accounting Research, 10, pp.205-37.

- Kaplan, R.S. and Norton, D.P. (1992). 'The Balance Scorecard - Measures that Drive Performance', Harvard Business Review, 70(1), pp.71-9.

- Kaplan, R.S. and Norton, D.P. (1996a).'Using the Balance Scorecard as a Strategic Management System', Harvard Business Review, 74(1), pp.75-85.

- Kaplan, R.S. and Norton, D.P. (1996b). 'Linking the Balanced Scorecard to Strategy', California Management Review, 39(1), pp.53-79.

- Kaplan, R. S. and Norton, D. P. (2000). The Strategy-Focused Organization: How Balanced Scorecard Companies Thrive in the New Business Environment. Harvard: Harvard Business School Press.

- Kaplan, R.S. and Norton, D.P. (2001). The Strategy-Focused Organization, Boston, MA: Harvard Business School Press.

- Kaplan, R.S., and Norton, D.P. (2003). Strategy Maps: Converting Intangible Assets into Tangible Outcomes. Boston, MA: Harvard Business School Press.

- Kaplan, R.S. and Norton, D.P. (2005). The Balanced Scorecard - Measures that Drive Performance. Harvard Business Review, July-August, Online version.

- Kennerley, M., and Neely, A. (2002). 'A Framework of the Factors Affecting the Evolution of Performance Measurement Systems', International Journal of Operations and Production Management, 22(11), pp.1222-1245.

- Laitinen, K. (1996). 'Framework for Small Business Performance Measurement-Towards Integrated PM Systems', Proceedings of the University of Vaasa. Research Papers (210), Business Administration (77), Vaasa, Accounting and Finance.

- Lee, C. and Yang, H. (2011). 'Organization Structure, Competition and Performance Measurement Systems and their Joint Effects on Performance ', Management Accounting Research, 22(2), pp.84-104.

- Letza, S. (1996). 'The Design and Implementation of the Balanced Scorecard', Business Process Reengineering and Management Journal, 2(3), pp.54-76.

- Lipe, M. G. and Salterio, S. E. (2000). 'Balanced Scorecard: Judgmental Effects of Common and Unique Performance Measures ', Accounting Review, 75(3), p. 283.

- Malina, M.A. and Selto, F.H. (2001). 'Communicating and Controlling Strategy: An Empirical Study of the Effectiveness of the Balanced Scorecard', Journal of Management Accounting Research, 13, pp.47-90.

- Malmi, T. (2001). 'Balanced Scorecards in Finnish Companies: A Research Note ',Management Accounting Research.12, pp.207-220.

- Mbogo, O. (2008). A Study of the Implementation of Balanced Scorecard as a Continuous Improvement Tool in Kenya Revenue Authority. Unpublished MBA Project, University of Nairobi.

- McCunn, P. (1998).'The Balanced Scorecard: the Eleventh Commandment', Management Accounting, December, pp.34-6.

- Murby, L. and Gould, S. (2005). Effective Performance Management with the Balanced Scorecard. Technical Report.[online] Available from: http://www.cimaglobal.com/Documents/ImportedDocuments/Tech_rept_Effective Performance Mgt_with Balanced Scd July 2005.pdf. (Accessed on: 28 March 2015).

- Neely, A, Gregory, M. and Platts, K. (2005). 'Performance Measurement System Design: A Literature Review and Research Agenda', International Journal of Operations \& Production Management, 25(12), pp.1228-1263.

- Neely, A., and Al Najjar, M. (2006). 'Management learning not Management control: The True role of performance measurement? 'California Management Review, 48(3), pp.101-114.

- Niven, P. R. (2002). Balanced Scorecard Step-by-Step: Maximizing Performance and Maintaining Results. New York: John Wiley \& Sons.

- Niven, P. R. (2006). Balanced Scorecard Step-by-Step: Maximizing Performance and Maintaining Results. ( $2^{\text {nd }}$ ed.) New York: John Wiley \& Sons.

- Norreklit, H. (2000). 'The Balance on the Balanced Scorecard - A Critical Analysis of Some of its Assumptions', Management Accounting Research, 11(1), pp.65-88.

- Norreklit, H. (2003).'The Balanced Scorecard: What is the Score? A Rhetorical Analysis of the Balanced Scorecard' ,Accounting, Organizations and Society, 28(6), pp.591-619.

- Nunnaly, J. (1978). Psychometric theory, New York: McGraw-Hill. 
- Nusair, K., and Kandampully, J. (2008). 'The antecedents of customer satisfaction with online travel services: a conceptual model.'European Business Review, 20(1), pp. 4-19.

- Nyaega. (2006).Application of Balanced Scorecard in Performance Measurement at Essar Telecom Kenya Limited. Unpublished MBA Project, University of Nairobi.

- Otley, D. (1999).'Performance Management: A Framework for Management Control Systems Research', Management Accounting Research, 10, pp.363-82.

- Othman, R. (2009). 'How Balanced Scorecard can Fail: Some Caves .'Borneo Bulletin, June 2.

- Othman, R., Ahmad Domil, A.K., Cheenik, Z., Abdullah, N. and Hamzah, N. (2006). 'A Case Study of Balanced Scorecard Implementation in a Malaysian Company ',Journal of Asia-Pacific Business, 7(2), pp.55-72.

- Öztürk, E. and Coskun, A.(2014). 'A Strategic Approach to Performance Management in Banks: The Balanced Scorecard ', Accounting and Finance Research.3 (3), pp.151-59.

- Pandey, I. M. (2005). 'Balanced Scorecard: Myth and Reality'. Vikalpa,30(1), pp.51-66.

- Panicker, S. and Seshadri, V. (2013). 'Devising a Balanced Scorecard to Determine Standard Chartered Bank's Performance: A Case Study.'International Journal of Business Research and Development. 2 (2), pp.35-42.

- Parker, C. (2000). Performance Measurement. Work Study, 2, pp.63-66.

- Phillips, P. and Louvieris, P. (2005). 'Performance Measurement Systems in Tourism, Hospitality, and Leisure SMEs: A Balanced Scorecard Perspective.' Journal of Travel Research. 44(2), pp.201-211.

- Poureisa, A., Bolouki, M., Ahmadgourabi, A. and Efteghar, A. (2013). 'Balanced Scorecard: A New Tool for Performance Evaluation ', Journal of Contemporary Research in Business. 4(1), pp.974-79.

- Qiu Zhang, H., and Wu, E. (2004). 'Human Resources Issues Facing the Hotel and Travel Industry in China', International Journal of Contemporary Hospitality Management, 16(7), pp.424-428.

- Quintano, A. (2009). Performance evaluation in the hospitality industry: The balance scorecard and beyond.[online]. Available from: www.icabr.com/fullpapers/Quintano\%Alfred.pdf. (Accessed on : 9 March $\underline{2015)}$.

- Rohm, H. (2002). 'Performance Measurement in Action', Perform, (2) 2, pp.2-5.

- Rohm, H. (2006). 'A Balancing Act .'Perform, (2) 2, pp.1-8.

- Salem, M.A., Hasnan, N., and Osman, N, H. (2012). 'Balanced Scorecard: Weaknesses, Strengths as its Ability as a Performance Management System versus Other Performance Management Systems ',Journal of Environment and Earth Science, 2, p. 9.

- Waruhiu, H. (2014). 'Rebalancing the Balanced Scorecard: A Sequel to Kaplan and Norton ',European Journal of Business and Management. 6 (29), pp.116-124.

- Whitaker, B. (2001). 'Mapping the Balanced Scorecard to the Baldridge and Presidents' Quality Award Criteria', Journal of Cost Management, 15(3), pp.25-29.

- Yilmaz, Y. and Bititci, U. (2006). 'Performance Measurement in the Value Chain: Manufacturing v. Tourism', International Journal of Productivity and Performance Management. 55 (5), pp.371-389.

- Zeglat, D., Alrawabdeh, W., Almadi, F. and Shrafat, F. (2012).'Performance Measurements Systems: Stages of Development Leading to Success ', Journal of Contemporary Research in Business. 4(7), pp.44048.

- Zhang, C., Pan, F. and Lin, T. (2013). 'Market Competition and the Use of Performance Measures in Chinese Firms',The Journal of Corporate Accounting \& Finance.pp.69-74. 